\title{
Is enhanced cognitive behaviour therapy effective for adolescents?
}

\author{
Anthea Fursland ${ }^{1 *}$, Susan Byrne ${ }^{1,2}$ \\ From 2013 ANZAED Conference: Inspiring Change: Person and Context \\ Melbourne, Australia. 23-24 August 2013
}

\section{Introduction}

The aim of this study was to examine the efficacy of enhanced cognitive behavioural therapy (CBT-E) for adolescents with the full range of eating disorders. There is robust evidence of the effectiveness of CBT-E for adults with eating disorders, including low weight patients. CBT-E has been adapted for adolescents and there is emerging evidence from one study $(\mathrm{N}=51)$ for its effectiveness in adolescents. This study aimed to add to the evidence base for the efficacy of CBT-E in adolescents with all forms of eating disorder.

\section{Methods}

The participants ( $\mathrm{N}=50,16-18$ years) were referred to a public outpatient clinic in Perth, Western Australia. 38\% had a BMI $<17.5$. Patients attended, on average, 25 individual CBT-E sessions, plus up to 4 family sessions.

\section{Results}

26 (52\%) completed treatment. Good outcome was achieved by $61.5 \%$ of treatment completers and $32 \%$ of the total sample. Compared to those $>18$ years referred to this service, the adolescents were more likely to complete treatment and their outcome was similar. The results also compare favourably to those reported in the only previous case series of CBT-E with adolescents.

\section{Conclusion}

There is encouraging evidence to support the use of CBT-E for adolescents.

This abstract was presented in the Children and Youth Treatment and Service Development stream of the 2013 ANZAED Conference.

* Correspondence: anthea.fursland@health.wa.gov.au

${ }^{1}$ Centre for Clinical Interventions, Australia

Full list of author information is available at the end of the article
Authors' details

${ }^{1}$ Centre for Clinical Interventions, Australia. ${ }^{2}$ School of Psychology, University of Western Australia, Australia.

Published: 14 November 2013

doi:10.1186/2050-2974-1-S1-O58

Cite this article as: Fursland and Byrne: Is enhanced cognitive behaviour therapy effective for adolescents? Journal of Eating Disorders 20131 (Suppl 1):O58.
Submit your next manuscript to BioMed Central and take full advantage of:

- Convenient online submission

- Thorough peer review

- No space constraints or color figure charges

- Immediate publication on acceptance

- Inclusion in PubMed, CAS, Scopus and Google Scholar

- Research which is freely available for redistribution
C Bïomed Central 